\title{
DROWNING OR WAVING? CITIZENSHIP, MULTICULTURALISM AND ISLAM IN MALAYSIA
}

\section{Steven Drakeley}

Senior Lecturer, Asian and Islamic Studies University of Western Sydney

\begin{abstract}
This article examines some intriguing shifts in Islamic thinking on questions around citizenship and multiculturalism that have emerged in the Malaysian context in recent years. It does so in the light of the March 2008 election results and other recent political developments, notably the rise of Anwar Ibrabim's PKR, and considers the implications for Malaysia. Of particular focus is the novel Islam Hadhari concept articulated by UMNO leader Prime Minister Badawi and the relatively doctrinaire Islamic state ideas of Islamist PAS. The article argues that these shifts in Islamic thinking are largely propelled by politics. Partly they are propelled by the logic, in a narrow political sense, imposed by the particular political circumstances that confront these Muslim-based political parties in Malaysia's multi-ethnic, multi-religious setting. Partly the impetus is derived from growing general concerns in Malaysia that a new and more stable and enduring settlement of the issues associated with the country's notorious borizontal divisions must be found if Malaysia is to avoid a disastrous plunge into communal conflict or tyranny.
\end{abstract}

Keywords: citizenship, multiculturalism, Islam Hadhari, Bumiputera 


\section{A. Introduction}

Citizenship, multiculturalism and Islam, and a broad range of associated issues interact in rather complex and unusual ways in Malaysia. Consequently, and because of its distinctive combination of social and political characteristics, Malaysia has consistently drawn considerable attention from political scientists, historians and sociologists. For the same reasons Malaysia is at the forefront of the current "global ijtihad" where many pressing contemporary problems confronting Muslim thinkers, policy makers and populations are being worked through. In particular Malaysia is highly relevant to the problems of pluralism and the politics of identity. Recently there have been some significant political developments in Malaysia, accompanied by some intriguing shifts in Islamic thinking on problems associated with citizenship and multiculturalism. This paper will survey these shifts in Islamic thinking in the Malaysian context, analyse the politics propelling them and consider the implications for Malaysia's future.

Malaysia is well known for its complex horizontal divisions. The key features of Malaysia's complex ethnic and religious composition can be gleaned from the following statistics. According to the 2000 census Muslims comprise $60.4 \%$ of the population, Christians $9.1 \%$, Hindus $6.3 \%$, Buddhists $19.2 \%$, Confucian and Taoist $2.6 \%{ }^{1}$ Furthermore, $65.1 \%$ of the population are bumiputra (indigenous), with Chinese and Indians comprising $26 \%$ and $7.7 \%$ of the population respectively. ${ }^{2}$ Each of these somewhat crude categories contains a number of self-identifying ethno-linguistic groups. Most politically significant in this regard is the composition of the bumiputra category. We know that overwhelmingly the bumiputra are Malay and Muslim, but there is some difficulty ascertaining the precise proportions. In a 2004 speech Prime Minister Abdullah Badawi stated that 54\% of Malaysia's population is Malay, but other sources give a lower figure,

${ }^{1}$ Census of Population and Housing Malaysia 2000, Department of Statistics Malaysia.

2 Bumiputra literally means "sons of the soil". 
only slightly above $50 \% .^{3}$ Since by definition Malays are Muslims, most of the bumiputra are Muslims, but there is a significant bumiputra Christian minority, mainly Iban and Kadazan from Malaysian Borneo. Approximately half of Malaysia's Christians are bumiputra. A number of important political implications flow from this complex pattern of horizontal identities. But the central defining political driver is that while the Malays are a majority, they are not a comfortable majority. The same applies to Malaysia's Muslims, although to a lesser extent since the size of the Muslim majority is significantly greater than that of the Malays.

\section{B. The Notoriety and Drama of the Malaysian Case}

The notoriety of the Malaysian case can be attributed to the unique and often seemingly contradictory association of several features. First, Malaysia is ostensibly a secular state with freedom of religion enshrined in the Constitution (Article 11). Secondly, Islam is the official religion (Article 3), a status which, supported by numerous legal and other measures, notably Article 21 A has effectively come to confer a privileged position upon Islam above other religions extant in Malaysia. Thirdly, religion and ethnicity are closely correlated in Malaysia, not only in the imagined community sense, but also legally with respect to the Malays who are defined by the constitution as people who are Muslim, speak the Malay language and follow Malay customs. There are Christians amongst the Indian, Chinese, and, as mentioned, amongst some of the indigenous communities. But Indians are

${ }^{3}$ For instance the CIA World Factbook (http://www.cia.gov/library/ publocations/theworld-factbook/print/my.html), accessed 19/12/2008, gives the Malay proportion of the population (as of 2006) as 50.4\% and other indigenous as $11 \%$. A possible reason for the discrepancy might be that Badawi has included Muslim indigenes of Borneo in the Malay category, a practice not without precedent but one that Borneans usually resent. The Malay category is certainly slippery. Many Malaysians with Indian, Arab or Chinese ancestry self-identify as Malay on the grounds that one parent is Malay, and are legally recognised as such, provided they are also Muslim. The Malay category also contains people who in another context might be identified or self identify as Acehnese, Minangkabau or Javanese. 
predominantly associated with Hinduism, although there is a significant number of Indian Muslims, and the Chinese are mainly associated with Buddhism, Taoism and Confucianism. And lastly, not only are religious and ethnic differences politicised in Malaysia but the Malaysia political system does so overtly. Malaysia's political system is openly founded on the assumption, organized incorporation and channelling of communal politics. ${ }^{4}$ No doubt that Islam is such a central factor adds considerable contemporary interest to the Malaysian case. But one suspects that the degree of interest, both scholarly and more general, is also due to the inherent drama of the Malaysian situation.

Malaysia is a prosperous nation, a developing country that is nearing developed status. Malaysia is also stable and peaceful. It is not a country torn apart by racial and religious conflict. Nor is Malaysia a country where its populace is the subject of a ruthless tyranny, like Burma or North Korea. Hence Malaysia's somewhat optimistic description by one scholar as a "unique model of tolerance and accommodation". ${ }^{5}$ And yet Malaysia's prosperity and peace rests upon the fragile stability of a compromise formula that seems impossible to sustain over the longer term. The formula seems inherently fragile because it involves a highly volatile mix of ethnicity, religion and politics. Thus there is a widespread view that sooner or later Malaysia's current prosperity and relative peace could give way abruptly to a nightmare of communal strife and/or heavy-handed authoritarian rule. That is unless Malaysia can develop and successfully implement a more stable and enduring settlement of the issues associated with its horizontal divisions. ${ }^{6}$ The drama resides in the suspense of waiting for

${ }^{4}$ This is termed a form of "authoritarian consociationalism" by Graham K. Brown, "The Formation and Management of Political Identities: Indonesia and Malaysia Compared”, Working Paper 10, February 2005, Centre for Research on Inequality, Human Security and Ethnicity, CRISE, Queen Elizabeth House, University of Oxford.

5 P.G. Riddell, “Malaysian Christians and Islamisation", in A. O’Mahony \& M. Kirwan (eds.), World Christianity: Politics, Theology, Dialogues, (London: Melisende, 2004), pp.226-256; cited in Albert Sundararaj Walters, "Issues in Christian-Muslim Relations: A Malaysian Christian Perspective", Islam and Christian-Muslim Relations, 18, 1, (January 2007), p. 67.

${ }^{6}$ In passing I note that Malaysia is also riven by centre-periphery and hierarchical divisions, but the horizontal are more significant. 
the situation to unfold, in the high stakes for Malaysia's population, and in the height of the fall from a position of considerable current grace should the compromise fail and large scale communal conflict or tyranny result.

Arguably, the likelihood of the compromise formula's eventual demise has not been reduced, but rather increased by its surprising longevity to date - it is now more than half a century old. Those sceptical of its capacity to endure for much longer the strains to which it is subject note that its longevity has rested upon three contingent and tenuous factors. The nation's prosperity has naturally worked to alleviate discontent and given many Malaysians tangible and considerable stakes in the status quo. Also, a complex of mutual fears has worked to discourage the discontented elements from upsetting the delicately balanced status quo. The fears are those felt by members of each community towards their communal others. But they are also the fears of the general costs to all of a communal conflagration, the fears of losing Malaysia's prosperity and peace and all the benefits that these bring. The final factor is the capacity and willingness of the state to preserve the status quo and to prevent outbreaks of communal violence. Fear of the state, in particular fear of its use of the notorious Internal Security Act's indefinite detention powers, is highly pertinent here. The sceptics also note that many Malaysians are dissatisfied with the compromise, and apparently are becoming increasingly so, adding to the pressures upon it.

One of the dimensions of discontent with the current arrangements is theological for a significant number of Malaysian Muslims. Indeed the compromise formula seems highly problematic from an Islam perspective, even allowing for the many and diverse understandings of Islam. The growing Islamic dissatisfaction with the peculiar Malaysian compromise is certainly a possible threat to peace in Malaysia. But it is also potentially the source of a more stable settlement. This will be my primary focus below, but first it would be useful to briefly survey the historical background. 


\section{Origins and Nature of the Compromise Formula}

During the century of colonial rule before independence on 31 August 1957 Malaysia's non-Malay population rose considerably. ${ }^{7}$ This was largely due to British policies which encouraged immigrant Chinese and Indian labour. By the 1930s Chinese comprised 39\% of the population and Malays a mere $44.7 \%$ of then British Malaya. ${ }^{8}$ Fearful that Malays were becoming a disadvantaged minority in their own land, a "Malay rights" movement emerged in the early C20th. It appealed to the British authorities to implement measures to safeguard Malay interests vis-à-vis the generally economically and educationally advantaged Chinese and Indians. A similar stance was adopted by the Malay political leadership when negotiating arrangements for independence after WWII.

In 1946, galvanised by the imminent prospect of a Britishdesigned independence in which democracy would feature, 41 Malay organisations came together to form the United Malay National Organisation (UMNO). This move prompted the reciprocal formation of the Malayan Chinese Association (MCA) and the Malayan Indian Congress (MIC). These organisations dealt with each other and with the British as the principal representatives of their respective communities. Moreover the British authorities accepted these representational claims. As such UMNO, the MCA and MIC lobbied and manoeuvred for the form of independence that would best advance their respective communities' interests qua communities. Malaysia appeared to be emerging as a classic case whereby democracy would accentuate communalism by politicising and hardening communal identities as politicians pursued and shepherded vote banks.

The leaders of these organisations were not oblivious to the serious dangers inherent in this situation, however. Nor did they fail to recognise their common interest in preserving the peace. Their solution

7 Technically this is the date of Malaya's independence. Malaysia was created on 16 September 1963. It consisted of Malaya (now Peninsular Malaysia), Sabah and Sarawak (Malaysian Borneo) and Singapore. In 1965 Singapore was expelled from the Federation.

${ }^{8}$ William R. Roff, The Origins of Malay Nationalism, (Kuala Lumpur: Universiti Malaya, 1974), p. 208. 
though was not to step back from the communal form of political organisation that they had adopted. On the contrary, far from abandoning ethnicity-based politics they decided to manage it by forming an alliance founded on a set of communal compromise arrangements. This alliance formula has proven to be a highly effective political vehicle. In one form or another, the UMNO-dominated alliance, the National Front (Barisan Nasional, or BN) has won every election since 1957. Each party draws votes from the ethnic community it purports to represent by appealing to its interests, but the votes for all three parties are pooled for the agreed alliance candidate. It is difficult to compete against this formula. Other community based parties can adopt a stronger pro-community line but they are easy to paint as dangerous extremists and can only attract the votes of one community. Parties can be formed on a non-ethnic basis, but, until recently at least, they have attracted few votes. A rival multi-ethnic coalition can be formed, but if so it merely confirms the formula.

As mentioned a set of communal compromise arrangements, often referred to as a "social contract", underpinned the successful alliance formula. It was clearly understood that the alliance would be dominated by UMNO with UMNO's leader becoming prime minister, thus ensuring Malay interests pre-eminence. In exchange the MIC and MCA got a voice in government. And everybody got communal peace. The eventual formula for independence reflected the spirit of this "gentlemen's agreement". Citizenship was granted fairly readily to nonMalays and freedom of religion was constitutionally guaranteed. In exchange the principle of special privileges for Malay citizens was enshrined. Moreover, the Head of State position was to rotate between the Malay sultans, Malay became the national language, ${ }^{9}$ and Islam was made the official state religion.

\section{Problems with the Malaysian "Social Contract"}

The "social contract" features a set of defensive measures designed to safeguard Malay interests. As well as Malay political

9 English and Malay were to be joint official languages for 10 years after which Malay would be the sole official language. 
dominance and pro Malay symbolic measures, a range of positive discrimination measures were also introduced. These were intended ostensibly to assist the Malay population (then overwhelmingly rural and poor) to catch up to the educational and economic levels of the other ethnic groups, principally to the Chinese. The usually unstated objective was to placate Malay public opinion and undercut the considerable impetus for more radical Malay chauvinistic demands (such as much more stringent citizenship tests for non-Malays). The measures were intensified after 1969 when an outbreak of racial riots was interpreted as indicating the dangerous persistence and depth of Malay resentment towards the other ethnic groups. The New Economic Policy (NEP) as it was called involved a range of profound positive discrimination measures, couched as "nation building". Officially the NEP policies were aimed at eradicating poverty altogether and erasing all links between ethnicity and economic role or position. Perhaps a little cynically, the stated policy aims are generally regarded as having merely provided an acceptable face for an upsurge of Malay chauvinism and for a re-casting of the independence bargain in terms more favourable to the Malays. The policies have certainly largely failed to achieve their stated aims, despite being extended well beyond their original term of twenty years. What they have done, unfortunately, is cement ethnic divisions and exacerbate ethnic tensions.

Both in 1957 and 1971 the affirmative action measures were considered a temporary necessity by many, particularly by Malaysia's non Malay citizens. Overwhelmingly, non Malays have always desired a Malaysia where all citizens are treated equally by the state irrespective of their ethnicity or religious beliefs. As the decades passed, and as the pro-Malay discrimination increased rather than reduced, the levels of non-Malay disgruntlement have risen. It became harder to believe that the measures were merely temporary. Similarly it became harder for non Malays to accept what they felt was second-class citizenship when they were born in Malaysia, and when increasingly their parents and grandparents, even great grandparents, were also.

Absurdities associated with the conflation of Malay with Islam exacerbated the resentment. Since Malay equated with Islam, it meant that all Muslims, including new converts and those of Arabic, Indian 
or Chinese background, could, under particular circumstances, qualify as Malay and therefore become eligible for special provisions (including highly profitable business advantages). Many other citizens deemed Malay were immigrants from Indonesia or the Philippines, sometimes including recent illegal arrivals, as well as many more whose family's presence in Malaysia could only be traced back one or two generations.

\section{E. Islamisation and the Escalation of non-Malay Concerns}

Non-Malay concerns increased with a demographic shift whereby the proportions of Muslims and Malays in the population appear to have risen significantly since independence. ${ }^{10}$ This shift might have been expected to alleviate Malay concerns and correspondingly reduced their attachment to the positive discrimination measures and to communal politics. But on the contrary (although actually there may be no causative correlation), as the Malay and Muslim proportions of the population have risen, Malay political dominance has been exerted to an even greater extent. This has resulted in a number of government policies which have escalated discontent and concerns on the part of other communities.

This tendency has gone hand-in-hand with an Islamisation phenomenon, sometimes referred to as an Islamic resurgence, dating particularly from the 1980s. It is of course not unique to Malaysia. A number of important dakwah (missionary)-oriented organisations emerged in Malaysia in the 1970s, particularly amongst young urban educated Malays, a social group which has dramatically increased since independence. Particularly prominent is Angkatan Belia Islam Malaysia (ABIM or Malaysian Muslim Youth Movement), from whose ranks sprang former Deputy Prime Minister Anwar Ibrahim, now leader of the opposition and prime ministerial aspirant. Also well-known in this regard is Darul Arqam, although it was banned for heresy in 1994, ${ }^{11}$

${ }^{10}$ Albert Sundararaj Walters, "Issues in Christian-Muslim Relations: A Malaysian Christian Perspective", Islam and Christian-Muslim Relations, 18, 1 (January 2007), p. 68.

${ }^{11}$ See Ahmad Fauzi and Abdul Hamid, "Inter-Movement Tension among Resurgent Muslims in Malaysia: Response to the State Clampdown on Darul Arqam in 1994", Asian Studies Review, 27, 3, (September 2003). 
and the once semi-clandestine Islamic Representative Council (IRC), now Jamaah Islam Malaysia (JIM or Society for Islamic Reform Malaysia). These groups have had a profound effect on the Islamic discourse in Malaysia and have contributed to considerably raised levels of self-conscious Islamic practice and identity for Malaysian Muslims. These factors have of course not failed to influence Malaysian politics. The two principal political parties supported by Malays, since before independence, are UMNO and Parti Islam Se-Malaysia (PanMalaysia Islamic Party, better known as PAS). PAS has always stood for an Islamic State, although it has not always emphasised this policy, and until recently had made little effort to spell out what this would entail for Malaysia. ${ }^{12} \mathrm{UMNO}$ has generally stood against the Islamic state concept, although Prime Minister Mahathir Mohamad somewhat ingenuously (but controversially) declared in 2001 that Malaysia was already an Islamic state. As competitors for the Malay vote, UMNO and PAS have engaged in periodic "bidding wars". For the first decades after independence the "bidding" was largely on the basis of which party best promoted Malay communal interests, but since the 1980s it has increasingly been couched in terms of an Islamic agenda for Malaysia. Partly this reflected a new ulama-based PAS leadership in 1983 which placed the ultimate objective of an Islamic state in Malaysia more to the fore. But the general Islamisation phenomenon alluded to above is the root cause. UMNO's successful strategy has always been to appropriate and modify PAS policies which appeared to be gaining traction. Thus PAS has always "outbid" UMNO, but UMNO has astutely judged how far it has needed to move in PAS's Malay chauvinist or Islamist direction in order to retain sufficient moderate Malay support. Indeed usually UMNO has retained a narrow majority of Malay votes. Of course UMNO can also rely on its alliance partners to deliver substantial votes for UMNO candidates, an advantage that PAS cannot emulate since members of the other communities can rarely be persuaded to vote for PAS candidates.

${ }^{12}$ PAS produced an official Islamic State document in November 2003. See Erica Miller, "Democratic Islamists? A Case Study on the Pan-Malaysian Islamic Party (PAS)", MA thesis, The Fletcher School, Tufts University, 2006, pp. 41-2. 
Malaysia's non-Malay communities are certainly unhappy about the increased pro-Malay ethnic redistributionism policies begun in the 1970s. But certain "Islamisation" measures begun in the 1980s whereby Malaysia's Islamic identity has been emphasised and Islam become steadily more privileged over the other religions has generated far greater levels of disquiet. From the perspective of Malaysia's non-Muslims they have increasingly encountered a range of discriminatory practices in the religious sphere and have become increasingly concerned that their civil liberties are under threat. It has been suggested that effectively many of the measures implemented in Malaysia amount to a de facto application of "traditional dhimmi (non Muslim minority) status" for non Muslims. ${ }^{13}$ Amongst the grievances commonly aired are claims of grossly disproportionate allocations of land for religious purposes. ${ }^{14}$ Christians have also complained of restrictions placed on Christian literature, such as on the use of the Malay and Iban bibles, while free range is given to Islamic literature, including the free dissemination of anti Christian polemical works. ${ }^{15}$

The greatest angst for non-Muslims has arisen from an amendment to a key section of the constitution in 1988. Article 121 (1A) provides that civil courts "shall have no jurisdiction in respect to any matter within the jurisdiction of the Sharia courts". ${ }^{16}$ Effectively this has created a jurisdictional dualism in Malaysia's legal system, and has overturned the previous constitutional situation whereby civil law had clear primacy. Many Malaysians, particularly non Muslims, regard this step as the thin end of the wedge whereby a quasi-theocratic state is slowly evolving within the framework of the secular Malaysian state. Encouraging this perception has been the way this article has been interpreted and implemented. It has led to a number of high profile cases related to apostasy and conversion where individuals dissatisfied

${ }^{13}$ S. Mark Heim, "A Different Kind of Islamic State: Malaysian Model”, The Christian Century, 121, 20 (October 5, 2004), p. 31.

${ }^{14}$ Albert S.Walters, "Issues in Christian-Muslim Relations”, pp. 72.

${ }^{15}$ Ibid., pp.74-75.

${ }^{16}$ Jaclyn Ling-Chien Neo, "Malay Nationalism, Islamic Supremacy and the Constitutional Bargain in the Multi-ethnic Composition of Malaysia", International Journal on Minority and Group Rights, 13, (2006), p. 111. 
with increasingly assertive Sharia-court rulings now have no legal redress. ${ }^{17}$ Non Muslims, and some Muslims, see this as being in fundamental contradiction with Article 11 which guarantees freedom of religion for all citizens.

Furthermore, some Muslims have advanced arguments which seek to alter the standard interpretation of the constitutional provision relating to Islam as the official religion of the Federation (Article 3.1). It has been interpreted in some quarters to justify a dominant position for Islam vis-à-vis other religions in law. Again this is an interpretation which seems quite at odds with the strong constitutional provisions guaranteeing freedom of religion and which, at least in the minds of the nation's founders, established Malaysia as a secular state. Tunku Abdul Rahman, the father of Malaysia and first prime minister, explicitly denied that Malaysia is an Islamic state. "I would like to make it clear that this country is not an Islamic State as it is generally understood, we merely provide that Islam shall be the official religion of the state. ${ }^{18}$ The behaviour of PAS-controlled governments in states such as Terengganu and Kelantan, where certain Sharia laws (according to the PAS interpretation of Sharia) have been implemented or mooted, is also pertinent here. ${ }^{19}$ PAS administrations have implemented laws prohibiting gambling and alcohol and imposed segregation of the sexes and dress codes. PAS has also enacted a Hudud criminal offences bills in 2002 in Terengganu and Kelantan and has made contradictory remarks about its application to non-Muslims. Although sometimes PAS has given assurances that these laws will only apply to Muslims, on more than one occasion PAS spokesmen have explicitly stated that eventually they will apply to non-Muslims. ${ }^{20}$ At present these Hudud

${ }^{17}$ Albert S. Walters, "Issues in Christian-Muslim Relations", pp. 76-77.

${ }^{18}$ Federal Legislative Council Debates, 1 May 1958, pp. 4671-2, quoted in Joseph M. Fernando, "The Position of Islam in the Constitution of Malaysia", Journal of Southeast Asian Studies, 37, 2, (June 2006), pp. 249-266.

${ }^{19}$ Erica Miller, "Democratic Islamists?”, pp. 46-54.

${ }^{20}$ Jaclyn Ling-Chien Neo, "Malay Nationalism, Islamic Supremacy and the Constitutional Bargain in the Multi-ethnic Composition of Malaysia", International Journal on Minority and Group Rights, 13, (2006), p. 105. Erica Miller, "Democratic Islamists?”, pp. 48. 
law measures have been blocked by federal authorities (as PAS knew they would be), so it remains to be seen what PAS would do in practice.

\section{F. Growing Concerns for Malaysia's Future}

It is not only non-Muslims who are unhappy with the "Islamisation" measures. Many Muslims, particularly urban, middle class and younger Muslims object to some or all of these policies. Similarly it is not only non-Malays who find the pro-Malay positive discrimination measures objectionable. Increasing numbers of Malays are moving to the view that such measures at least need to be wound back. There are a number of reasons for this phenomenon, but the over-arching explanation is a growing concern across all horizontal identities for Malaysia's future if the current trajectory were to continue. There is a growing feeling that the original set of arrangements has been distorted to the point where the original communal bargain has been broken, or at least it is now superseded. Consequently Malaysia's social fabric, democracy, and economy are all under threat and a new course is needed.

Amongst other things, these critics note the significant economic cost to Malaysia of the policies that have prevailed over the last few decades. There is a significant "brain drain" of talented non-Malays who feel their prospects are better overseas and there is a significant cost in terms of market inefficiencies associated with the positive discrimination policies. The economic costs spiralled dramatically as these policies moved far beyond spheres such as education into the realm of multi-million dollar development contracts. Apart from the economic costs, there have also been considerable political and social costs associated with this phenomenon due to nepotism and political corruption. $^{21}$

But most glaring is that more than half a century on from independence the ethnic and religious landscape of Malaysia not only remains highly politicised, but social tensions have risen sharply rather than dissipated. Religious and ethnic divisions in Malaysia are more

${ }^{21}$ Edmund Terence Gomez, "The Perils of Pro-Malay Policies", Far Eastern Economic Review, 168, 8, (September 2005). 
sharply delineated than they were several decades ago. There is less inter-ethnic and inter-religious mixing and even less apparently does a sense of belonging to Malaysia (Malaysian nationalism and/or Malaysian citizenship) predominate over ethnic and/or religious group membership. Walters cites a 2000 survey carried out Universiti Malaysia which indicated that $98 \%$ of Malay students did not mix with non Malays, with similar results for Chinese and Indians' mixing. ${ }^{22}$ Other surveys reveal starkly different views corresponding to Malay versus non Malay on particular public issues. ${ }^{23}$ It was not supposed to be this way. The positive discrimination measures were supposed to alleviate Malay resentment and pave the way for harmony. Ominously, disquiet over these trends has recently begun to produce a more strident response from non-Muslims and non-Malays, who for the most part have remained stoic since the 1960s. ${ }^{24}$

\section{G. Recent Developments and Shifts in Islamic Thinking}

The most obvious recent development which is pertinent here is the general election held in March 2008. The UMNO-dominated BN retained power but for the first time in Malaysia's history was pushed very close by the opposition alliance (Barisan Alternative or BA). The BA comprises the DAP (Democratic Action Party), PAS and Anwar Ibrahim's People's Justice Party (PKR) which campaigned strongly on equality of opportunity for everybody. The opposition won just under half of the popular vote, an impressive achievement given the huge advantage of incumbency that accrues to the government in the Malaysian context. ${ }^{25}$ Although this high vote for the BA only trans-

${ }^{22}$ Albert Sundararaj Walters, "Issues in Christian-Muslim Relations: A Malaysian Christian Perspective", Islam and Christian-Muslim Relations, 18, 1, (January 2007), p. 72.

${ }^{23}$ Carolyn Hong, "Growing Unease over race debate", Straits Times 21/11/08.

${ }^{24}$ Danny Lim "Rallying for Rights in Malaysia". Far Eastern Economic Review, December 2007. Simon Montlake, "Race Politics Hobbles Malaysia", Far Eastern Economic Review, March 2008, Vol.171. No.2. Jan Stark, "Indian Muslims in Malaysia: Images of Shifting Identities in the Multi-ethnic State", Journal of Muslim Minority Affairs, 26, 3, (December 2006), p. 392.

${ }^{25}$ There are many claims of electoral abuse practiced by the government in Malaysia. For a discussion of some of these see Thomas B. Pepinsky, "Malaysia: Turnover Without Change", Journal of Democracy, 18, 1 (2007), pp. 113-127. 
lated into 88 of 222 seats in the federal parliament and control over five out of 13 states, it did mean that for the first time the government lost the two thirds majority needed to amend the constitution. Interestingly, Malay votes divided almost equally between $\mathrm{BN}$ and $\mathrm{BA}$ but young and urban Malays voted overwhelmingly for the opposition regardless of the ethnicity of the opposition candidate. ${ }^{26}$ Thus the election does perhaps presage a major turning point for Malaysia in the sphere of horizontal divisions and reflects a significant shift in public attitudes and thinking.

Ironically Prime Minister Mahathir Mohamed, renowned as a champion of Malay interests and the principal architect of the "Islamisation" shift, himself perhaps began the shift in thinking. In February 1991 while launching his Vision 2020 (whereby Malaysia is to become a fully developed country by 2020); he stated that there was a need to develop a Bangsa Malaysia (Malaysian nationality). It was only talk at the time, and his policies, perhaps unintendedly to a degree, actually pushed hard in the opposite direction. But this was a radical concept for both historical and linguistic reasons. The term is strikingly similar to Lee Kuan Yew's 1964 campaign slogan which called for "a Malaysian Malaysia" (as opposed by implication to a Malay Malaysia which is how the social contract appeared to non-Malays). The controversy engendered by this campaign led directly to Singapore's expulsion from Malaysia in 1965. The historical allusion emphasised that this represented a call for a sharp shift in thinking. But perhaps the most significant (and positive) aspect of the language employed by Mahathir is that the term bangsa had previously almost always been utilised with chauvinistic overtones, most commonly with respect to calls to defend the Bangsa Melayu (Malay People). Bangsa is

${ }^{26}$ Ahmad Fauzi Abdul Hamid, "Islamist Realignments and the Rebranding of the Muslim Youth Movement in Malaysia", Contemporary Southeast Asia, 30, 2 (2008), p. 233. 
one of those slippery terms that can mean people, race or nationality. ${ }^{27}$ Clearly realization of the concept of a Bangsa Malaysia would imply abandonment of, or at least a drastically reduced adherence to, notions of separate ethnic identities.

The shift in thinking on the issues of horizontal division has a prominent Islamic dimension. In fact there has always been a view held by some Malaysian Muslims that Malay privileges and Malay chauvinism are incompatible with Islamic teachings which oppose discrimination based on ethnicity. Until more recently however it was a view largely confined to the issue of ethnic divisions amongst Malaysian Muslims.

This is a longstanding issue with respect to those Malaysian Muslims whose ethnicity places them in the Indian category, or who have Indian and Malay ancestry. The former are often still derogatorily termed "mamak, ${ }^{28}$ a Tamil word for uncle, whereas the latter used to be termed Jawi Peranakan, a term which denoted Muslims who were descended from South Indian backgrounds through the male line and Malay through the female line. During the 1930s the more extreme exponents of a Malay chauvinist stance defined a Malay as "a man whose male parent is a native of this Malay Peninsula or of any of the neighbouring islands of the Malay Archipelago". ${ }^{29}$ This definition effectively excluded Jawi Peranakan but included Indonesians; a clear indication that ethnicity rather than religion was the primary criterion of Malay identity for these Malay chauvinists. To some extent this attitude still lingers. ${ }^{30}$ Many Malaysian Muslims with Indian heritage

${ }^{27}$ Heng Pek Koon "Chinese responses to Malay hegemony (1957-1996), in Zawawi Ibrahim (ed.), Cultural Contestations: Mediating Identity in a Changing Malaysian Society, (London: ASEAN Academic Press, 1998), pp. 51-82, cited in Graham K. Brown, "The Formation and Management of Political Identities: Indonesia and Malaysia Compared”, Working Paper 10, February 2005, Centre for Research on Inequality, Human Security and Ethnicity, CRISE, Queen Elizabeth House, University of Oxford, p. 23.

${ }^{28}$ Jan Stark, "Indian Muslims in Malaysia: Images of Shifting Identities in the Multi-ethnic State", Journal of Muslim Minority Affairs, 26, 3, (December 2006), p. 384.

${ }^{29}$ Quoted in William, R. Roff, The Origins of Malay Nationalism, (Kuala Lumpur: Universiti Malaya, 1974), p. 245.

${ }^{30}$ Interestingly, Malays of Arab descent are far less likely to experience this problem. 
are now accepted as Malay as testified by two high profile examples: Anwar Ibrahim and Mahathir Mohamed. But many others are not accepted as Malay and thus are denied the coveted bumiputra status. ${ }^{31}$ Other Indian Muslims are strongly disinclined to seek acceptance as Malays, proudly retaining their Indian Muslim identity. Those in the latter categories, who are also excluded from political representation through the Hindu Tamil-dominated MIC, have recently become more vociferous about their plight. In so doing they highlight this uncomfortable issue of the ethnicity-religious identity nexus for Muslims in Malaysia.

The first significant shift in thinking on the issue of ethnic privileges beyond the Muslim community came from what many would have regarded as an unlikely source. In May 1983 new PAS president, Yusof Rawa, shifted PAS dramatically away from its erstwhile Malay chauvinist stance and condemned NEP-associated policies as assabiyah (tribalism). ${ }^{32}$ Few non-Malays welcomed this new PAS stance with much enthusiasm however since it was accompanied by a much more avowedly Islamist position. Since then although never abandoning its Islamist standpoint, PAS has grappled within its Islamist framework, with the issue of Malaysia's substantial religious minorities and has at times made serious efforts to reach out beyond its Muslim constituency. No doubt the endeavour has been pursued sincerely for the most part, but there is considerable suspicion that PAS's overtures have been driven by opportunistic motives. Certainly PAS is acutely aware of its political dilemma. Unless it can attract substantial non-Muslim votes, to win power democratically (and PAS are democratic Islamists) PAS would need to garner almost every Muslim vote. Even if it could accomplish this unlikely prospect in competition with UMNO and others it would still be confronted by the Malaysian reality of a substantial non-Muslim minority.

${ }^{31}$ Jan Stark, "Indian Muslims in Malaysia: Images of Shifting Identities in the Multi-ethnic State", Journal of Muslim Minority Affairs, 26, 3, (December 2006), p. 384.

${ }^{32}$ Liow, Joseph Chinyong Liow and Rohaiza Ahmad Asi, "Political Islam in Southeast Asia: One Ummah, Many Narratives", Harvard Asia Pacific Review, 9,2, (Spring 2008); p. 560 and Erica Miller, "Democratic Islamists?”, p. 28. 
The only other democratic path to power for PAS is through a coalition, a strategy it has pursued with shifting degrees of enthusiasm all of its political life. But here too this entails establishing a modus vivendi with non Muslim political forces. PAS has certainly made considerable efforts in recent years to woo non Muslim voters and to make it an attractive alliance partner through issuing re-assurances about its intentions. It has campaigned with the slogan "PAS for all" and in the recent elections even ran a young female Hindu candidate in an UMNO stronghold (one it couldn't win) using its non-Muslim PAS supporters club. ${ }^{33}$ Such efforts are not particularly convincing however while PAS pursues its Islamist agenda in places like Terengganu, but they have produced significant electoral gains for PAS, notably in 1999 and 2008. But moves in this direction always seem to elicit a counter reaction within PAS which undermines the gains. Clearly there is a tug of war taking place within PAS between what have been termed the pragmatists and the purists. ${ }^{34}$ The publication in 2003 of PAS's Islamic state document authored by the "purists" was partly responsible for PAS losing all its gains in the 2004 elections. The same process seems to be underway again as a purge of the so-called "Erdogans" (referring to Turkey's liberal Muslim president) who are considered pro-Anwar Ibrahim has begun, a development which does not bode well for the opposition alliance. ${ }^{35}$

The primary factor driving the re-examination of these issues and the resultant modest moderation of PAS's Islamist position is the inescapable reality of Malaysia's religious and ethnic composition. As PAS Deputy President Nasharuddin Mat Isa stated in 2006: we have to be realistic ... [Malaysia] is not an overwhelmingly Muslim-majority country ....we have to make the party more relevant to multi ethnic

${ }^{33}$ Abdul Halim Taib, "Malaysia PAS Fields Non-Muslim Candidate", www.islamonline.net, accessed 29/11/2008.

${ }^{34}$ William F. Case and Liew Chin-Tong, "How Committed is PAS to Democracy and How Do We Know It?”, Contemporary Southeast Asia, 28, 3 (2006) pp. 385-406.

${ }^{35}$ Zubaidah Abu Bakar, "Pas Begins to Axe 'Erdogan' Faction”, New Straits Times, 24/11/2008. 
multi cultural and multi religious Malaysia". ${ }^{36}$ The other crucial factor in this regard of course is Malaysia's democratic political system. While far from perfect, indeed famously classified as a quasi-democracy by Huntington, Malaysian democracy imposes a particular political logic which encourages moderation and compromise. It is this which also has assisted in pushing the rather strange bedfellows of PAS and PKR into alliance. Ironically, it is also the restrictions on democracy that operate in "soft authoritarian" ${ }^{37}$ Malaysia which have made these two forces see eye to eye more than perhaps they otherwise might. To a considerable extent their politics have been shaped by the anti democratic measures which have been employed against them by the government over the years. While some observers are cynical about the degree of PAS's commitment to democracy, ${ }^{38}$ it is undeniable that PAS has been remarkably consistent and more than a little courageous in its campaigns for transparency in government and for democracy, not least with respect to its opposition to the ISA.

In keeping with its urban, multi-ethnic, more educated and cosmopolitan constituency, PKR's position on Malaysia's ethnic and religious issues is far more liberal than that of PAS. Anwar Ibrahim's campaign for democracy, civil liberties, civil society and good governance since 1998 is well known beyond Malaysia. But within Malaysia his stance on the former issues is perhaps even better known. His call for narrowing "the economic divide regardless of ethnic lines" is a politically courageous stance in the Malaysian context. ${ }^{39}$ Certainly he is a prominent advocate of the compatibility between Islam and liberal democracy, but beyond that his theological views are a little harder to pin down. He began his political career as an avowed Islamist, emerging as leader of ABIM and regarded as somewhat close to PAS.

\footnotetext{
${ }^{36}$ Quoted in William F. Case and Liew Chin-Tong, "How Committed is PAS", p. 397.

${ }^{37}$ Gordon P. Means, "Soft Authoritarianism in Malaysia and Singapore”, Journal of Democracy, 7 (October 1996), pp. 103-17.

${ }^{38}$ See William F. Case and Liew Chin-Tong, "How Committed is PAS”, pp. 385406.

${ }^{39}$ Anwar Ibrahim, "Radical Islam in Southeast Asia", Far Eastern Economic Review, (November 2006), p. 39.
} 
It is from this position that he was plucked by Mahathir Mohamed into UMNO and government, moving accordingly to a more centrist, moderate Islamist position. He has a reputation as a progressive Muslim, but it is unclear to what extent this description is theologically as opposed to politically accurate. Perhaps he is not inclined to spell his thinking out on these issues too clearly given his need to balance an unwieldy coalition which includes committed opponents of liberal Islam like PAS.

The most interesting development in Islamic thinking in the Malaysian context on these questions is that promoted since 2003 by current Prime Minister Abdullah Badawi. Badawi, a man with sound Islamic credentials and considerably more theological grounding than his predecessor Mahathir, was perhaps uniquely placed to seek a new, more moderate Islamist theological footing for UMNO. The set of ideas that Badawi is promoting are based on a concept termed Islam Hadhari or civilisational Islam. It features somewhat vague appeals to an Islamic vision for development for Malaysia, including in the fields of education and economics. It advocates integrity (read clean government), social progress and social harmony, in which context it stresses the Islamic ethic of protection of minorities. The idea is to "engage the broader universal principles of Islam". ${ }^{40}$ Clearly Islam Hadhari has echoes of liberal Islamic thought, albeit perhaps faint ones.

As was the case for PAS, the impetus for UMNO's Islamic "rethink" is primarily political, driven by UMNO's emerging political dilemma and shaped by UMNO's political calculations. As Malaysian politics as a whole steadily moved in a Malay chauvinist and Islamist political direction, UMNO always moved with it, sufficient to retain the relatively moderate but thereby commanding position it has always occupied within the political spectrum. Changes in the political landscape however make UMNO's position increasingly difficult. Now UMNO faces a new challenge as it is squeezed between the continuing Islamist pressure of PAS on one side and a resurgent liberal democratic and secular-tinged opposition on the other. UMNO can no longer afford to appropriate watered-down PAS Islamist policies, sufficient to stem

${ }^{40}$ Mohammad Hashim Kamali quoted in New Straits Times 8/10/08. 
the flow of Malay votes to PAS, while remaining confident that it will retain moderate Malay support and that of the other communities. Moderate Malay and Muslim voters now have a viable alternative in $\mathrm{PKR}$, as do former MIC and MCA voters. Accordingly, UMNO needed to find a platform from which it could fight effectively on both fronts.

Islam Hadhari has provided UMNO with an ideological weapon which has shored up its Islamic credentials. PAS has always presented itself as the keepers of the "true Islam" and painted UMNO as unIslamic. Its success in this regard has rested to a significant extent on its claims to Islamic theological authority, an impression reinforced by its persistent reiteration of an unbending Islamist ideology. Now UMNO is better able to compete with PAS on its own theological ground, armed with an alternative Islamic ideology underpinned by its own claims to Islamic authority. UMNO has gone to some lengths to bolster the religious authority of Islam Hadhari. Badawi has offered Islam Hadhari to the Muslim world, promoting it as the way forward as an "antidote to the tide of extremism". ${ }^{41}$ In this vein the Malaysian government hosted a World Al-Azhar Alumni conference in February 2008 and secured endorsement for the concept from international delegates. ${ }^{42}$ Thus no longer does UMNO's Islamic position seem so apologetic and compromised by an "un-Islamic" attachment to "Western" values. Now UMNO adopts a more assertive stance, insisting that its moderation is squarely within the authentic and mainstream tradition of Islam. This stance also supports the charge that UMNO has always levelled against PAS (with some success post 9-11), that PAS is extremist. Now this is not merely a political charge, it is also theological, since by implication if it is UMNO that is squarely within the authentic Islamic tradition with Islam Hadhari then PAS cannot be.

Islam Hadhari has also provided a basis for UMNO to seek to repair its reputation with the non-Muslim communities and with the disaffected cosmopolitan Malays attracted to the Anwar Ibrahim

${ }^{41}$ Ioannis Gatsiounis, "Islam Hadhari in Malaysia, Current Trends in Islamist Ideology, 3, 16( February, 2006).

42 "Islam Hadhari Suitable as Foundation of New Islamic Civilisation", Bernama Daily Malaysian News, (18 February 2008). 
alternative. The Islam Hadhari concept promised a more inclusive and pluralistic Islam, clean government, and continuation of Malaysia's drive towards economic development and modernity. The election results suggest that Islam Hadhari had relatively little appeal to this constituency. As Anwar Ibrahim and other critics have pointed out, there appears to be a substantial gap between the government's Islam Hadhari rhetoric and the reality of its practice. But perhaps the election result would have been even worse without Islam Hadhari which allowed the government to present a less threatening "Islamic face" while remaining within an Islamic discourse.

While faint, the liberal Islamic notes in Badawi's Islam Hadhari concept were certainly too loud for PAS which condemns civilisational Islam. PAS does so in predictably literalist terms, as bidah (innovation) and thus blasphemy. PAS President Abdul Hadi Awang's book, Islamic Civilisation not Civilisational Islam (Hadharah Islamiyyah bukan Islam Hadhari) damned it for allowing a compartmentalised Islam alongside un-Islamic elements, effectively a hybrid, new religion. ${ }^{43}$ Other Islamist forces in Malaysia were not much more welcoming. ABIM offered qualified acceptance of civilisational Islam but regards liberal Islam as a "stealthy scheme" which seeks "to subvert the primary role of Islam in Malaysia's polity". ${ }^{4}$

Nevertheless, notwithstanding any intrinsic deficiencies or the criticisms mounted against Islam Hadhari, the very advancement of these ideas by the definitively mainstream and politically important UMNO is a significant development. It remains to be seen whether the concept will continue to be promoted after Badawi's prime ministership, although his likely successor his deputy Najib Tun Razak has pledged to do so. ${ }^{45}$ But at the very least the concept is a further

${ }^{43}$ Ahmad Fauzi Abdul Hamid, "Islamist Realignments and the Rebranding of the Muslim Youth Movement in Malaysia", Contemporary Southeast Asia, 30, 2 (2008), p. 223.

${ }^{44}$ Ibid., p, 224 and p. 228.

${ }^{45}$ Shahanaaz Habib, "Najib to continue promoting Islam Hadhari", The Star, 13 November, 2008. Badawi has announced he will step down in March 2009 for Najib Razak. In the interim Anwar Ibrahim continues to attempt to wrest the prime ministership through defection of sufficient $\mathrm{BN}$ members of parliament to the $\mathrm{BA}$. 
indication of the attempts that range right across the Malaysian Islamic political spectrum to chart a new course for Malaysia through the problems associated with the country's complex and dangerous horizontal divisions. While it is promising that a start has been made there is as yet no substantial progress. There is no consensus amongst Malaysia's Muslims on the way forward and nothing has been done to redress the grievances of the non-Muslim communities.

\section{H. Conclusion}

In May 1959, Tunku Abdul Rahman reiterated his assurance that Malaysia was not an Islamic state. Exasperated he remarked: "Unless we are prepared to drown every non-Malay, we can never think of an Islamic Administration". ${ }^{46}$ While of course no serious political force in Malaysia has ever advocated ethnic cleansing, non-Muslim Malaysians might regard an Islamic state as their figurative drowning. Partial moves in this direction, combined with excessive pro-Malay positive discrimination policies, have brought Malaysia close to disaster. The majority of the population, including it would seem a majority of Malaysia's Muslims recognise this. It appears that Malaysia has stepped back from the brink and is undertaking a re-evaluation of the country's problems associated with its horizontal divisions.

Abdul Rahman put his finger on the essence of the problem in his above statement. The reality is that while Malaysia's non-Muslim population is a minority it is a very substantial one $-40 \%$. It is simply not realistic to contemplate implementation of an Islamic state in such a context, particularly if it is conceived in a classical sense with dhimmi provisions and the like. Something along those lines could only possibly function effectively and without massive repression in a situation where non-Muslims constituted a much smaller minority. Only PAS, and a small number of much smaller organisations, appear not to fully appreciate this reality. But even PAS is aware of the problem and is

${ }^{46}$ Quoted in Jaclyn Ling-Chien Neo, "Malay Nationalism, Islamic Supremacy and the Constitutional Bargain in the Multi-ethnic Composition of Malaysia", International Journal on Minority and Group Rights, 13, (2006), from F.R. von der Mehden, 'Religion and Politics in Malaya', Asian Survey 3, 12, (1963), pp. 609-615, quoting Straits Times, (1 May 1959). 
Steven Drakeley

struggling with the issue, seeking ways consistent with its literalist theological understanding of Islam to accommodate Malaysia's plural population structure.

A Bangsa Malaysia remains quite some way off, if it ever does eventuate. Although a poll of Malaysian youth in 2004 indicated majority support for the concept and for removal of political parties based on ethnicity. ${ }^{47}$

${ }^{47}$ Ibid., p. 117. 


\section{BIBLIOGRAPHY}

Abu Bakar, Zubaidah, “Pas Begins to Axe 'Erdogan' Faction”, nstonline, http://www.nst.com.my/Current_News/NST/Monday/ Columns/2410070/Article/pppuaccessed 25/11/2008.

Brown, Graham K, "The Formation and Management of Political Identities: Indonesia and Malaysia Compared", Working Paper 10, February 2005, Centre for Research on Inequality, Human Security and Ethnicity, CRISE, Queen Elizabeth House, University of Oxford.

Case, William F. and Liew, Chin-Tong, "How Committed is PAS to Democracy and How Do We Know It?", Contemporary Southeast Asia, 28, 3, (2006).

Census of Population and Housing Malaysia 2000, Department of Statistics Malaysia.

Chok, Suat Ling, "Time for Change is not here yet", New Straits Times, Kuala Lumpur, 16/11/2008.

Fernando, Joseph M, "The Position of Islam in the Constitution of Malaysia", Journal of Southeast Asian Studies, 37, 2, (June 2006).

Fuller, Thomas, "Malaysia on the Brink of a Dramatic Makeover Anwar, Resurgent, Pledges to Upend Power Structure", International Herald Tribune, Paris, (15/9/2008).

Gatsiounis, Ioannis, "Islam Hadhari in Malaysia, Current Trends in Islamist Ideology, 3, (16 February, 2006).

Gomez, Edmund Terence, "The Perils of Pro-Malay Policies", Far Eastern Economic Review, 168, 8, (September 2005).

Habib, Shahanaaz, "Najib to Continue Promoting Islam Hadhari", The Star, (13 November).

Hamid, Ahmad Fauzi Abdul, "Islamist Realignments and the Rebranding of the Muslim Youth Movement in Malaysia", Contemporary Southeast Asia, 30, 2, (2008).

—, "Inter-Movement Tension Among Resurgent Muslims in Malaysia: Response to the State Clampdown on Darul Arqam in 1994", Asian Studies Review, 27, 3, (September 2003). 
Heim, Mark S., "Different Kind of Islamic State: Malaysian Model", The Christian Century, 121, 20 (October 5, 2004).

Hong, Carolyn, "Malays Feeling Uneasy as Minority Races Become More Strident", Straits Times, (21/11/2008).

"Islam Hadhari Suitable as Foundation of New Islamic Civilisation", Bernama Daily Malaysian News, (18 February, 2008).

Jomo, K.S, and Cheek, Ahmad Shabery, "Malaysia's Islamic Movements", in Kahn, Joel S. and Loh, Francis Kok Wah, Fragmented Vision: Culture and Politics in Contemporary Malaysia, North Sydney: Allen and Unwin, 1992.

Kissel, Mary, "The Malaise of Enforced Inequality", The Australian, $(3 / 11 / 2008)$.

Liow, Joseph Chinyong and Asi, Rohaiza Ahmad, "Political Islam in Southeast Asia: One Ummah, Many Narratives", Harvard Asia Pacific Review, Spring 2008.

Means, Gordon P., "Soft Authoritarianism in Malaysia and Singapore", Journal of Democracy 7 (October 1996).

Miller, Erica, "Democratic Islamists? A Case Study on the PanMalaysian Islamic Party (PAS)", MA thesis, The Fletcher School, Tufts University, 2006.

Montlake, Simon, "Race Politics Hobbles Malaysia", Far Eastern Economic Review, 171, 2, (March 2008).

Neo, Jaclyn Ling-Chien, "Malay Nationalism, Islamic Supremacy and the Constitutional Bargain in the Multi-ethnic Composition of Malaysia", International Journal on Minority and Group Rights, 13, (2006).

"Nik Aziz Questions Islamic Scholars' Recognition for Islam Hadhari", Bernama Daily Malaysian News, (26 February, 2008).

Peletz, Michael G, "Islam and the Cultural Politics of Legitimacy: Malaysia in the Aftermath of September 11", in Robert W. Hefner (ed.), Remaking Muslim Politics: Pluralism, Contestation, Democratization, Princeton and Oxford: Princeton University Press, 2005.

Pepinsky, Thomas B., "Malaysia: Turnover Without Change", Journal of Democracy, 18, 1 (2007). 
Roff, William R., The Origins of Malay Nationalism, Kuala Lumpur: Universiti Malaya, 1974.

Stark, Jan, "Indian Muslims in Malaysia: Images of Shifting Identities in the Multi-ethnic State", Journal of Muslim Minority Affairs, 26, 3, (December 2006).

Taib, Abdul Halim, "Malaysia PAS Fields Non-Muslim Candidate", www.islamonline.net, accessed 25/11/2008.

Walters, Albert Sundararaj, "Issues in Christian-Muslim Relations: A Malaysian Christian Perspective", Islam and Christian-Muslim Relations, 18, 1, (January 2007).

Yong, Huey Jiun, "Pluralism and the Hadhari concept", New Straits Times, Kuala Lumpur, (8/10/2008). 
Steven Drakeley 